\title{
Variația diacronică și cîmpul lexical. Implicații teoretice și practice
}

\author{
Dinu Moscal* \\ Institutul de Filologie Română „A. Philippide”, Str. T. Codrescu 2, 700481 Iași, România
}

\section{Despre articol \\ Istoric:}

Primit 3 mai 2015

Acceptat 14 iunie 2015

Publicat 17 iulie 2015

Cuvinte-cheie:

diacronie

evoluția limbilor

diferențiere dialectală

istoria limbii

semantică istorică

\begin{abstract}
Rezumat
Articolul de față are în vedere importanța variației diacronice în cadrul cercetărilor dedicate cîmpului lexical, precum şi implicațiile la nivelul aplicaţiilor practice. Se disting două perspective de cercetare majore în domeniu, cea tradițională, lipsită de un instrumentar propriu-zis pentru o cercetare semantică, și cea modernă, care beneficiază de contribuțiile aduse de lingvistica structurală. Este pusă în evidență importanța pe care o are variația diacronică pentru fiecare dintre aceste două perspective, precum și impactul la nivel practic. Dacă în cazul primei perspective, analiza dicronică a unui cîmp onomasiologic este o trăsătură definitorie, cadrul teoretic al perspectivei moderne exclude cercetarea variației unui cîmp, atît în plan diacronic, cît și în plan sincronic. În partea finală a articolului este arătată importanța descrierii din perspectiva modernă a unui cîmp lexical la fiecare nivel al variației sale, sincronice sau diacronice. Acest fapt conduce la o identificare mai exactă a semnificației cuvintelor ce fac parte dintr-un cîmp în cadrul fiecărei variante a unei limbi istorice. De asemenea, este exemplificată utilitatea acestor rezultate în cadrul lexicografiei.
\end{abstract}

\section{Cadrul general}

Sintagma „cîmp lexical” este asociată imediat cu ideea cercetării unui grup de cuvinte, ceea ce este adevărat, însă acest adevăr nu trebuie să se confunde cu scopul cercetării cîmpurilor lexicale, care nu este o analiză pentru ele însele, ci pentru decelarea unei identități cît mai clare a elementelor semnificativ-designative ale limbii, adică lexemele (sau, într-o accepție mai largă, cuvintele), pe baza raporturilor pe care acestea le dezvoltă în cadrul anumitor paradigme la nivel semantic. În realitate, analiza cîmpurilor lexicale (numite și cîmpuri semantice) nu este altceva decît continuarea demersului lui Saussure de a da consistență conceptului de 'valoare lingvistică, atunci cînd vorbește despre raporturile asociative bazate pe analogia semnificaților (Saussure, 1922, p. 171).

Identificarea prin diferențiere este în fapt un proces de cunoaștere uman primar, corelat cu genul proxim, însă nu și cu variabilitatea unităților ce formează genul proxim. Prima confruntare cu variabilitatea în cadrul definirii prin gen proxim și diferență specifică este probabil întîmplarea relatată de Diogenes Laertios, cînd Platon este nevoit să reconsidere definiția pentru 'om', în urma modificării artficiale a unui cocoș de către Diogene Cinicul. Astfel, definiția omului ca ,animal biped și fără pene” ar fi fost completată cu specificarea „care are unghii late” (Diogenes, 2001, p. 203). Provocarea lui Diogene, prin aducerea în fața lui Platon a unui cocoș jumulit, este, desigur, și un fapt anecdotic, însă răspunsul lui Platon este o ilustrare cît se poate de simplă a modului în care o variabilă poate influența definirea prin genul proxim și diferență specifică.

Același proces este indicat de Saussure în cazul cunoașterii unităților lingvistice, atunci cînd accentuează importanța conceptului de 'valoare lingvistică’ „En outre l'idée de valeur, ainsi déterminée, nous montre que c'est une grande illusion de considérer un terme simplement comme l'union d'un certain son

*Adresă de corespondență: dinumoscal@yahoo.com. 
avec un certain concept. Le définir ainsi, ce serait l'isoler du système dont il fait partie; ce serait croire qu'on peut commencer par les termes et construire le système en en faisant la somme, alors qu'au contraire c'est du tout solidaire qu'il faut partir pour obtenir par analyse les éléments qu'il renferme" (Saussure, 1922, p. 157).

Identificarea unităților lingvistice prin diferențiere—sau, utilizînd un termen consacrat în lingvistică, prin opoziție-implică și un alt aspect primar, și anume faptul că limba nu este o nomenclatură. Afirmația făcută de Saussure vizează planul designativ, și nu poate fi negată, chiar dacă în unele cazuri vorbim și despre existența unor nomenclaturi. Însă acest aspect trebuie pus în evidență și la nivelul semnificativ al limbii. Așa cum nu există o corespondență biunivocă între unitățile unei serii a numelor şi unităţile unei serii a lucrurilor, în același fel nu există o corespondență biunivocă între unitățile seriei semnificanților și unitățile seriei semnificaților. Altfel spus, limba nu are caracter de nomenclatură nici la nivel designativ, nici la nivel semnificativ. Desigur, nu s-a făcut afirmația că limba ar fi o nomenclatură la nivel semnificativ, însă acastă problematizare este necesară pentru a arăta de ce sau cum nu este aici o nomenclatură. Răspunsul teoretic este cel dat de Saussure în citatul de mai sus, continuat prin discutarea raporturilor asociative bazate pe analogia semnificatului. Această direcție de cercetare, fundamentală prin obiectul de studiu, a fost continuată prin obiectivul descoperirii acestor raporturi la nivelul paradigmatic al limbii, care relevă existența unor grupuri, numite cîmpuri lexicale sau cîmpuri semantice, obiectiv avut în vedere începînd îndeosebi cu anii '30 ai secolului trecut.

\section{Obiectul cercetării}

Conceptul de 'cîmp lexical' are un istoric de aproape un secol, iar diferitele abordări teoretice au adus în prim planul cercetărilor distincțiile lingvistice de primă importanță de la nivelul general al limbii avute în

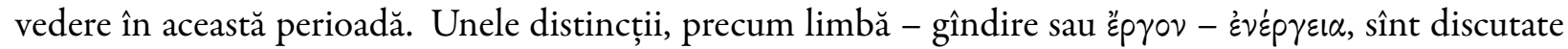
doar în cercetările de început în domeniu (Trier, 1973a, p. 1-8), iar în alte cazuri distincțiile au fost apropriate diferit, ceea ce a condus la imagini diferite ale cîmpului lexical (Jolles, 1973; Porzig, 1973). Distincția sincronie - diacronie este una esențială pe tot parcursul cercetărilor dedicate cîmpului lexical, atît în planul metodei, cît și în planul obiectului, adică atît în delimitarea teoretică a obiectului de studiu „cîmp lexical”, cît și în analiza propriu-zisă a unui cîmp lexical. Obiectivul prezentei cercetări este urmărirea impactului perspectivei diacronice în aceste două planuri și relevarea utilității acestui tip de analiză, în special în preluarea rezultatelor practice în lucrările lexicografice.

\section{Perspectiva tradițională și perspectiva modernă}

Istoricul cercetărilor dedicate cîmpului lexical indică existența a două etape majore distincte, fapt probat prin obiectivele principale ale acestora: o primă etapă în care se aduc argumente pentru a susține existența cîmpurilor lexicale, ceea ce implică în mod natural și demersuri de delimitare a acestui obiect de cercetare, şi o a doua etapă, axată pe descrierea raporturilor dintre elementele ce formează un cîmp lexical și distincția faţă de alte tipuri de raporturi, acestea din urmă corespunzînd altor tipuri de paradigme lexicale. Prima etapă este reprezentată de lexicologia germană dintre anii '30 și '60, în primul rînd prin cei doi mari lexicologi germani, Jost Trier și Leo Weisgerber. A doua etapă este reprezentată de studiile lui Eugenio Coseriu, care reanalizează întreaga problematică utilizînd instrumentarul oferit de lingvistica structurală. Acestor două etape le corespund două abordări științifice diferite ale cîmpului lexical, determinate în mare parte și de obiectivul principal al fiecăreia, dar și de stadiul lingvisticii în perioada respectivă. Se disting astfel două perspective diferite, numite în continuare „perspectiva tradițională” și „perspectiva modernă”.

\section{Perspectiva tradițională și variația diacronică}

Studiile din prima perioadă nu relevă o viziune unitară asupra conceptului de 'cîmp lexical', însă teoria cea mai bine conturată și care s-a impus a fost aceea a lui Trier, susținută şi continuată de Weisgerber, care oferă şi o primă tipologie a cîmpurilor lexicale (Weisgerber, 1973). 
În demersul său de a studia vocabularul german de pînă în secolul al XIII-lea pentru conceptul de 'cunoaștere' (v. germ. „Verstand”), Trier (1973a) caută să găsească o modalitate de prezentare care să depășească modaliatea oarecum intuitivă de a prezenta conținutul semantic al cuvintelor. În acest scop, Trier are în vedere stabilirea unei perspective unitare și a unei metode de cercetare, prin care să se demonstreze interdependența și transferul de conținut semantic între cuvintele ce formează o paradigmă semantică bazată pe raporturi la nivelul conținutului lexical. Spre deosebire de încercările anterioare din domeniu, Trier caută să precizeze nivelul de limbă la care se constituie un cîmp lexical și natura raporturilor ce se stabilesc între cuvintele ce-l compun. Modalitatea considerată drept cea mai adecvată pentru înțelegerea limbii la nivelul lexicului este ca acesta să fie perceput ca un întreg în interiorul căruia se pot contura unități conceptuale, care se definesc prin dependență de unitățile lexicale cele mai apropiate prin conținutul semantic: „Sprachinhaltsforschung ist Gliederungsforschung [...]. Denn man kann wohl von einer Ganzheit und ihrer Gliederung zum einzelnen Element, dem Wort gelangen, aber es ist hoffnungslos, durch Reichung von Wortbedeutungen zum Ganzen des Wortschatzinhaltes vordringen zu wollen. Man gelangt durch Reihung und Zusammenzählung nie zum Ganzen” [„A cerceta conținutul limbii înseamnă a cerceta structura sa [...]. Pentru că, fără îndoială, de la un întreg și de la structura sa se poate ajunge la unitatea componentă, la cuvînt, însă intenția de a ajunge la conținutul lingvistic al vocabularului ca întreg prin înşiruirea semnificaţiilor cuvintelor este lipsită de şanse. Prin înşiruire şi adiţionare nu se ajunge niciodată la întreg"] (Trier, 1973b, p. 117). Această percepție o urmează pe aceea a lui Saussure, cînd acesta vorbește despre conceptul de 'valoare’: „En outre l'idée de valeur, ainsi déterminée, nous montre que c'est une grande illusion de considérer un terme simplement comme l'union d'un certain son avec un certain concept. Le définir ainsi, ce serait l'isoler du système dont il fait partie; ce serait croire qu'on peut commencer par les termes et construire le système en en faisant la somme, alors qu'au contraire c'est du tout solidaire qu'il faut partir pour obtenir par analyse les éléments qu'il renferme" (Saussure, 1922, p. 157). Pentru a demonstra existența cîmpurilor lexicale, dar mai ales pentru a le da o identitate, Trier a utilizat anumite distincții lingvistice generale, dintre care cîteva se vor regăsi mai tîrziu la Coseriu (2001b) sub numele de „distincții primare” („distinctions préalables”). Distincțiile avute în vedere de Trier sînt: limbă

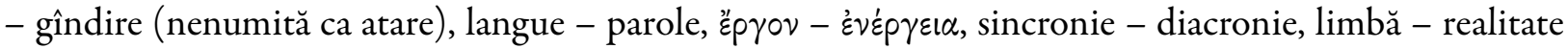
(Trier, 1973a, p. 1-26; cf. Moscal, 2013, p. 40-63).

Distincțiile sînt discutate atît referitor la limbă în general, cît și privitor la nivelul lexical al limbii, unde ar trebui să se distingă cîmpurile lexicale, care reprezintă structurarea lingvistică a complexului conceptual (neorganizat) corespondent (Trier, 1973a, p. 1). Cu excepția ultimei dihotomii, limbă - realitate, care este o distincție între lingvistic și extralingvistic, în cazul celorlalte dihotomii cîmpul lexical nu este situat niciodată în mod tranşant de o anumită parte a acestora.

În ceea ce privește sincronia și diacronia, în mod clar raporturile dintre elementele unui cîmp lexical nu pot fi identificate decît în plan sincronic. Asocierea cu staticul și, respectiv, cu dinamicul în limbă era și continuă încă să fie un fapt în general acceptat în studiile de lingvistică. Perspectiva sincronică este asociată studiului unei „stări” de limbă, în timp ce perspectiva diacronică este asociată studiului evoluției unei unități a limbii. Avîndu-se în vedere dimensiunile relativ reduse ale unui cîmp lexical, Trier consideră că în cercetarea sa pot fi combinate ambele perspective, în sensul că delimitării în sincronie a cîmpului lexical i se poate adăuga analiza în diacronie. Astfel, cîmpul lexical este în terminologia saussureană, atît o realitate sincronică, cît și o realitate diacronică. De altfel, Trier se raportează la această separare între realități (și identităţi) sincronice și diacronice și afirmă că diacronia unui cîmp reprezintă un pas înainte faţă de direcția stabilită de Saussure în acest domeniu: „Saussure hat den Schritt nicht getan, der hier versucht wird: von Querschnitt zu Querschnitt springend die Strukturgeschichte eines Feldes zu geben” ["Saussure nu a făcut pasul care va fi încercat aici: redarea istoriei structurii unui cîmp trecînd de la secțiune la secțiune”] (Trier, 1973a, p. 13). Trier consideră că raporturile dintre elementele limbii și întregul ei nu aparţin numai lingvisticii sincronice şi că lingvistica diacronică trebuie să urmărească nu doar linii izolate, adică istoria unui anumit fapt de limbă în diferite stadii sincronice, aşa cum consideră Saussure. De asemenea, el consideră că separarea lingvisticii sincronice de cea diacronică este o monstruozitate științifică 
(Trier, 1973b, p. 118-119). Mai mult, asocierea dintre sincronic și static nu este acceptată de Trier, în virtutea istoricității limbii: „Es ist kein Einwand gegen Saussure, wenn man behauptet, die Sprache als ein historisch Gewordenes unewig sich Wandelndes spotte der Einordnung in die Fächer und Schublade nirgend welcher statischer Ordnungen” [„Nu este un reproș la adresa lui Saussure să afirmi că limba ca devenire istorică și permanentă transformare își rîde de repartizarea în rafturi și sertare a unei dispoziţii statice"] (Trier, 1973a, p. 11-12).

Trier face o analiză a cîmpului lexical al domeniului reprezentat prin germ. „Verstand” (cunoaștere), arătînd transformarea sa de la starea iniţială, reprezentată prin trei termeni: wîsheit, kunst și list. Inițial, wîsheit (înțelepciune, cu sensul de „cunoaștere spirituală, cu raportare la divinitate și moralitate”), avea un caracter de știință supraordonată celor reprezentate prin kunst (artă, cu sensul de „cunoaștere teoretică, rezervată curții” care cuprindea nediferențiat ceea ce astăzi este desemnat în limba germană prin Wissenschaft 'știință, Gelehrsamkeit 'erudiție', Kunst 'artă', Bildung 'cultură', la care se adăuga arta comportamentului în tot ceea ce înseamnă viața curții, eticheta) și list (meșteșug, cu sensul de „abilitate tehnică”). Spre sfîrşitul secolului al XIII-lea wîsheit își pierde caracterul general și intră în serie cu ceilalți doi termeni. Întregul sistem al domeniului „Verstand” (cunoaștere) se restructurează: kunst desemnează sferele superioare ale cunoașterii, wizzen desemnează cunoașterea în general și ceea ce a fost desemnat prin list (abilitatea tehnică), iar wîsheit desemnează cunoașterea religioasă (chiar cu tentă mistică).

În acest fel înțelege Trier diacronia unui cîmp și acesta devine însuşi scopul cercetării sale, adică stabilirea semnificației fiecărui cuvînt prin delimitarea sa în interiorul unui cîmp şi urmărirea modificării raporturilor în funcție de orice variație a semnificației vreunui termen din interiorul cîmpului din care face parte acesta: „Diese ist unser Ziel. Feldgliederungswandel wird uns hier beschäftigen” [„Acesta este scopul nostru. Preocuparea noastră o constituie modificarea raporturilor din interiorul cîmpului"] (Trier, 1973a, p. 18). Urmărirea în plan diacronic a modificărilor din interiorul unui cîmp reprezintă pentru Trier modul optim de a analiza istoric vocabularul unei limbi: „Zur Sprachgeschichte gehört eine Geschischte der Feldaufteilungen, oder vom Worte hergesehen eine Geschichte des Wortschatzes nach Feldern” [„O istorie a structurii cîmpului sau, privind dinspre cuvînt, o istorie a vocabularului pornind de la cîmpuri face parte din istoria limbii"] (Trier, 1973a, p. 20-21).

În studiile ulterioare dedicate problematicii cîmpului lexical, Trier-influențat și de unele studii apărute între timp—reinterpretează dihotomia metodologică sincronie-diacronie și consideră că afirmația lui Saussure despre imposibilitatea îmbinării perspectivei sincronice cu cea diacronică („L'opposition entre les deux points de vue-synchronique et diachronique-est absolue et ne souffre pas de compromis”, Saussure, 1922, p. 119) nu este adecvată cercetării limbii și că, dimpotrivă, se dovedește a fi necesară: „Saussures Cours de linguistique générale wurde mir früh bekannt und wichtig. Für die Klärung des Gedankens von der Interdependenz der Elemente verdanke ich dem Buche viel. Aber seinem Verbot, synchronische und diachronische Sprachbetrachtung zu verbinden, konnte ich mich nicht unterwerfen” ["Cursul de lingvistică generală al lui Saussure mi-a fost cunoscut și a fost important [pentru mine] încă de timpuriu. Datorez mult acestei cărți în ceea ce privește clarificarea gîndirii prin interdependența dintre elemente. Însă interdicției sale de a combina perspectiva sincronică a limbii cu cea diacronică nu mă pot conforma”] (Trier, 1973c, p. 459). Argumentele pentru această abatere de la principiul lui Saussure urmează niște observații făcute de Walther von Wartburg cu privire la necesitatea cercetării diacronice în vederea stabilirii semnificației unui cuvînt, deoarece în unele situații perspectiva sincronică este insuficientă şi poate conduce la descrieri false ale unei realități lingvistice (Wartburg, 1931; 1972; 1946, p. 123-177).

Demonstrația lui Wartburg este cunoscută în special prin problematica evoluției în dialectul gascon a lat. gallus în raport cu evoluția lat. cattus. Devenind omonime la un moment dat, se ajunge la înlocuirea termenului omonim pentru lat. gallus în gasconă ${ }^{*}$ gat printr-un sinonim existent în acel moment în limbă, bigey (< lat. vicarius), fapt care nu ar putea fi înțeles fără combinarea perspectivei sincronice cu cea diacronică: „Darin liegt der innere kausale Zusammenhang zwischen der Diachronie A-B, die das Wort bigey als pittoreskes Synonymon neben gallus «Hahn» stellt, und der Synchronie B, deren Spannung bigey an die Stelle von gallus treten lässt. Nur durch eine Verbindung der beiden Betrachtungsweisen ist es in 
jener Abhandlung möglich geworden, Gilliérons Beispiele zu interpretieren, als er selbst es getan hat, und ihnen einen neuen Sinn zu geben” [,În spatele acestui fenomen stă interdependența cauzală internă dintre diacronia A-B, care pune cuvîntul bigey ca sinonim pitoresc lîngă gallus, și sincronia B, a cărei tensiune face ca bigey să ia locul lui gallus. Numai printr-o corelare a celor două perspective s-au putut interpreta în acea lucrare exemplele lui Gilliéron altfel decît a făcut el însuși și li s-a putut da un nou înțeles”] (Wartburg, 1972, p. 6). Însă, așa cum a observat însuși Trier, întreaga demonstrație a lui Wartburg se sprijină tot pe teoria elaborată de Saussure (Trier, 1973b, p. 123).

Concluzia lui Trier este că există o interdependență între lingvistica sincronică și cea diacronică și în cadrul cercetării cîmpurilor lexicale, însă acest lucru nu modifică esențial dihotomia saussuriană, ci este doar o dezvoltare a ei. În definitiv, este vorba despre înțelegerea unei evoluții în limbă prin adoptarea perspectivei din momentul respectiv, un cuvînt nefiind egal cu sine însuși în diferitele stări de limbă în decursul istoriei. Acesta este și obiectul de studiu al lui Trier, numai că la aceste inegalități se adaugă și reconstituirea echilibrului din jurul său, adică analiza cîmpului lexical.

Trier echivalează semnificația sintagmei cîmp lexical cu istoria unui cîmp onomasiologic, deoarece, pentru el, descrierea unui cîmp lexical presupune delimitarea unui cîmp onomasiologic și a semnificaţiei fiecărui cuvînt prin raportare la celelalte cuvinte din acest cîmp, apoi urmărirea în timp a acestei structuri complete a cîmpului cu observarea deplasării semnificației cuvintelor în întregul cîmpului: „Die Feldbetrachtung ist ein praktisches Hilfsmittel, und sie ist ein solches aus einer Notlage der praktischen Wortforschung entstanden, nämlich aus einer Notlage der diachronisch arbeitenden Bezeichnungslehre, der historischen Onomasiologie” [„Perspectiva cîmpului este un instrument auxiliar practic și a apărut ca atare dintr-o necesitate de cercetare practică a cuvîntului, și anume dintr-o necesitate a unei teorii a semnificației analizate diacronic, a unei onomasiologii istorice"] (Trier, 1973b, p. 456).

Așadar, diacronismul reprezintă una dintre trăsăturile esențiale ale cîmpului lexical la Trier. Delimitarea cîmpului lexical se face în sincronie, însă dependenţa conturării semnificaţiei elementelor componente de raportarea reciprocă se demonstrează în diacronie, unde orice modificare la nivelul unui element se reflectă în sistemul cîmpului respectiv. Concluzia sa este că există o interdependență între perspectiva sincronică și cea diacronică: „Unter dem Leitstern des Gedankens der Umgliederung ist das Ineinandergreifen von deskriptiver und historischer Sprachwissenschaft nun auch da hergestellt, wo es sich um Sprachinhalte und ihre Änderungen handelt” [„Astfel, și în cazul în care este vorba despre conținutul lingvistic și transformările la care este supus, se dovedește că principiul conducător al ideii de reorganizare este interdependența dintre lingvistica descriptivă și cea istorică”] (Trier, 1973c, p. 128).

Studiul cîmpului lexical din ambele perspective, precum și accentuarea perspectivei diacronice trebuie să fie percepute în contextul știinţific al momentului respectiv. Saussure impusese realităţile lingvistice sincronice, însă acestea erau situate la nivelul abstract al limbii. Pentru cercetarea unei realități concrete nu existau încă mijloacele lingvistice necesare cu ajutorul cărora să se demonstreze diferențele de conținut semantic dintre cuvintele ce formează un cîmp lexical. Singura posibilitate de a demonstra interdependența dintre elementele unui cîmp era descrierea sa diacronică, această descriere arătînd transferuri de conținut de la un termen la altul și reașezarea structurii unui cîmp în raporturi noi. Așadar, se poate spune că diacronismul nu era o opțiune în acest caz, ci singura posibilitate metodologică pe care o oferea lingvistica din acel moment. Se poate afirma că Trier şi von Wartburg au fost constrînşi de limitele lingvisticii de atunci să demonstreze interdependența și transferul de semnificație într-un cîmp lexical prin abordarea sa diacronică. Alți lingviști care au abordat problema cîmpurilor lexicale nu au avut în vedere într-un mod explicit raportul dintre sincronie și diacronie.

\section{Perspectiva modernă și variația diacronică}

Întreaga problematică a cîmpurilor lexicale va fi preluată mai tîrziu de Eugenio Coseriu. Contribuțiile sale reprezintă a doua etapă majoră a istoricului cercetărilor în domeniu, etapă distinctă de prima nu prin alegerea unei perioade istorice propriu-zise, ci printr-o analiză dintr-o nouă perspectivă a aceleiași reali- 
tăţi. Primul său articol în care este tratată problematica cîmpurilor lexicale (Coseriu, 2001a) se axează pe posibilitatea descrierii raporturilor dintre semnificați prin utilizarea instrumentarului oferit de lingvistica structurală. Semantica diacronică structurală propusă nu are însă în vedere diacronia unei limbi, ci trecerea unor structuri dintr-o limbă în alta, adică din latină în limbile romanice. În acest context, trebuie menționat că semantica structurală nu este pentru Coseriu o ,structuralizare” a lexicului unei limbi, adică ceea ce se așteptau să găsească primii teoreticieni ai cîmpului lexical, ci doar identificarea zonelor structurate ale lexicului (Coseriu, 2001a, p. 274-275).

În ceea ce privește variabilitatea limbii, Coseriu s-a situat mereu la nivelul limbii „funcționale”, definită astfel: „obiectul la care se gîndea Ferdinand de Saussure și pe care îl visa este această limbă funcțională, sistemul lingvistic unitar nu numai sincronic, ci sintopic, sinstratic și sinfazic, fără diferențe nici în sus și în jos, nici la dreapta și la stînga" (Coseriu, 1994, p. 60). Așadar, problema variației diacronice nici nu apare discutată propriu-zis de Coseriu, lucrul de care se preocupă fiind găsirea unei limbi care să nu conțină nici variațiile sincronice. Acest lucru nu trebuie interpretat ca o îndepărtare a variației din studiul unei limbi, ci doar că fiecare variație „funcțională”, adică o variație care implică alte opoziții, aparține unei alte limbi funcționale, cum ar fi un dialect sau grai sau un jargon.

De altfel, Coseriu afirmă în mod clar acest lucru: „Cela ne signifie pas non plus qu’on devrait ignorer la variété de la langue («description structurale» ne signifie aucunement «réduction» de la langue historique à un seul système). Cela signifie uniquement que tout opposition doit être établie et décrite dans la langue fonctionnelle à laquelle elle appartient et que, pour chaque point d'un domaine quelqonque de la langue, la description doit être faite autant de fois qu'il y a des structures différentes, devant une «langue» à décrire, on décidera, en chaque cas, si sa différenciation interne est telle quelle exige qu'on la decrive comme une «collection» de langues différentes ou s'il y a lieu d'en choisir une langue fonctionnelle de base et d'opter pour une description «à étages» de tous les points de sa structure pour lesquelles des différences diatopiques, diastratiques ou diaphasiques se présentent, par rapport à la langue fonctionnelle choisie" (Coseriu, 2001b, p. 243-244).

O astfel de descriere „pe etaje” ar avea și cîmpurile lexicale ale unei limbi, descriere care ar putea include, pe lîngă diferențele diatopice, diastratice sau diafazice, și diferențele diacronice, acestea din urmă nefiind altceva decît foste diferențe diatopice, diastratice, sau diafazice (cf. Wartburg, 1946, p. 123-177). Însă descrierea „pe etaje” a rămas doar o prezentare teoretică, neexemplificată. Lucrările lui Coseriu au în vedere doar descrierea sincronică a cîmpurilor lexicale. Semantica structurală oferă posibilitatea descrierii conținutului unui cuvînt printr-o sumă de unități semantice semnificative. În acest fel, diferențele de conținut pot fi cuantificate, ceea ce dă posibilitatea unei analize clare a elementelor unui cîmp lexical în plan sincronic, și anume a identificării conţinutului semnificativ distinctiv, acesta fiind constituit din una sau mai multe trăsături semantice. De altfel, structura unui cîmp lexical poate fi stabilită numai în sincronie. O perspectivă diacronică ar presupune urmărirea modificărilor ce apar la nivelul raporturilor din cadrul unui cîmp, o dată cu modificarea unuia sau mai mulți termeni din interiorul acestuia. De exemplu, un cuvînt precum rom. mîndru se află în trei zone diferite ale lexicului limbii române. Cu primul sens, cel etimologic ('înțelept, inteligent'), el intră în raport cu termenii din limba română veche a căror semnificație acoperă domeniul capacității intelectuale. Cu primul sens derivat, 'frumos', el intră în raport cu termenii din limba română veche a căror semnificație acoperă domeniul frumuseții, dar cu același sens intră și la nivelul popular. Ce cel de-al treilea sens, 'orgolios', atestat deja la finalul sec. XVII, el intră în raport cu termenii a căror semnificație acoperă domeniul atitudinii omului față de sine și semenii săi.

\section{Implicațiile practice ale variaţiei diacronice în cadrul celor două perspective}

Perspectiva tradițională, asimilată istoriei unui cîmp onomasiologic a avut două reflexe la nivelul practic al cercetării lingvistice. Un prim efect, imediat și în concordanță cu teoria, este lucrarea lui Hallig \& Wartburg (1963), unde se propune de fapt o nouă lexicografie prin asimilarea contribuțiilor aduse de cercetările dedicate cîmpurilor lexicale. Scopul lucrării este de a propune un nou mod de organizare a 
unui dicționar printr-o exemplificare a unei secțiuni din vocabular, în care ordinea cuvintelor să fie cea conform ariei semantice din care fac parte, și nu cea alfabetică. Această iniţiativă nu poate fi urmată decît pentru mici secțiuni din lexic, ceea ce s-a și întîmplat, de altfel, însă cu o adăugare a perspectivei diacronice, care se constituie ca un al doilea efect la nivel practic al teoriei tradiționale. Ceea ce pentru Trier a fost un instrument pentru a demonstra existența raporturilor din interiorul unui cîmp semantic, a devenit mai tîrziu un obiectiv în lucrări de lexicologie dedicate unor cîmpuri onomasiologice, deși în titlu apare sintagma „cîmp lexical”. În plus, acestea ignoră noua direcție dată prin lucrările lui Coseriu, chiar dacă acestea din urmă sînt mențioanate cel puțin în introducerea teoretică. Multe dintre acestea sînt lucrări valoroase, dar nu urmează în nici un fel teoria cîmpurilor lexicale. O lucrare de acest tip de un înalt nivel științific este cea a lui Escobedo Rodríguez (2001). Astfel de lucrări nu continuă nici perspectiva tradițională, dar nici perspectiva modernă, care este una sincronică, centrată pe relevarea tipurilor de raporturi dintr-un cîmp lexical.

Perspectiva modernă nu are în vedere diacronia, ci propune o cercetare de tip sincronic, ceea ce nu înseamnă că ignoră variația diacronică, așa cum, de fapt, nu o ignoră nici pe cea sincronică. Ceea ce impune perspectiva modernă este metoda, adică delimitarea conținutului unui cuvint la nivelul de limbă în care funcționează cu o anumită semnificație. De exemplu, un cuvînt precum lopată dezvoltă o opoziție echipolentă în unele zone din Bucovina cu cuvîntul șufle (< germ. Schaufel 'lopată): lopată / cu vîrf rotund/ : șfle /cu vîrf rectangular/. Termenii în opoziție echipolentă au un nucleu comun și o trăsătură distinctivă egală valoric cu cele ale termenilor din cîmpul respectiv. Insistența lui Coseriu pentru identificarea semnificației și a opozițiilor în cadrul unei limbi funcționale nu înseamnă altceva decît adecvarea cercetării la realitatea avută în vedere. Lopată cu trăsătura semică / cu vîrf rotund/ și raportul cu şufle nu poate fi valabil decît la nivel regional în zona menționată. Altfel, lopată nu comportă nici trăsătura semantică /cu vîrf rotund/, nici trăsătura semantică /cu vîrf rectangular/. O variație de același tip, însă în plan diacronic, se constată în cazul termenilor vechi și bătrîn. De la raportul de sinonimie valabil în limba română veche se ajunge la opoziția echipolentă între termenii vechi (pentru entități non-vii) și bătrîn (pentru entități vii) ${ }^{1}$. Acești doi termeni se află astăzi într-o opoziție sinonimică, adică sint parasinonimi, însă în limba română veche ei sînt sinonimi, deoarece bătrîn, ca și vechi, era folosit atît pentru entități vii, cît și pentru entități nonvii $^{2}$. Cunoașterea opozițiilor de la nivelul semantic lexical, pe baza cărora se constată existența unui cîmp lexical, ar trebui să se reflecte și în tratamentul lexicografic al termenilor respectivi. DA prezintă adjectivul bătrîn astfel: „1. (Despre oameni) Foarte înaintat în vîrstă (în opoziție cu tînă r, ju n e) [...]. 2. P. e x t. De demult, din vremuri vechi”. O definiție bazată pe rezultatele analizei specifice a cîmpurilor lexicale ar trebui să dea caracteristica comună /perioadă lungă de timp/ pentru ambii termeni, cu specificarea /pentru entităţi non-vii/ la vechi și / pentru entități vii/ la bătrîn. Schimbarea raportului dintre termeni în plan diacronic ar putea fi specificat ca „(vechi) Vechi” în cadrul articolului pentru adjectivul bătrîn și ca restricție în cadrul aticolului pentru adjectivul vechi din limba română veche, nu ca o extensie a semnificației actuale, cum apare în DA, ceea ce nu corespunde realităţii istorice a limbii române.

\footnotetext{
${ }^{1}$ Utilizarea semului /viu/ (pentru entități vii), în locul celui de /ființă/ (pentru ființe) (cf. Coseriu, 2001a, p. 307), necesită o argumentare. De exemplu, pielea, care nu este ființă, îmbătrînește, dacă este „vie”. Despre pielea unei persoane în vîrstă se spune că e îmbătrîn i tă, și nu ,învechită”. În schimb, despre pielea „ne-vie”, cea care se folosește în industria pielăriei, se spune că e în v e c h i tă. Nu la fel se întîmplă și în cazul limbii italiene, de exemplu, unde avem vecchio pentru obiecte, plante și animale, dar și pentru persoane (în mod peiorativ sau la nivelul colocvial: Questo vestito ti invecchia) și anziano numai pentru persoane, însă pielea este „i n v e c c h i a ta” (cf. Iliescu, 2008).

${ }^{2}$ Pentru a ilustra acest fapt, redăm cîteva exemple din Ghibănescu (1906-1915), cu indicarea volumului şi paginii pentru sursă și a anului între paranteze: „seamnele ceale bătrăne” $I_{2}, 234$ (a. 1632), „hotarăle ceale bătrăne” II 1 , 164 (a. 1638), ,casăle ceale bătrăne” $\mathrm{II}_{2}, 44$ (a. 1643), „vad de moară bătrân” $\mathrm{II}_{2}, 47$ (a. 1644), ,care sat este mai bătrân” III 1 , 48 (cca 1647), „siliștea cea bătrână” $\mathrm{II}_{2}, 156$ (cca 1648), „zapis bătrân” II 2,187 (a. 1649), „obcina cea bătrână” $\mathrm{III}_{1}, 86$ (a. 1657), „moșie bătrănă” IV ${ }_{1}$, 86 (a. 1686), „Zapisăle cele bătrâne” $I_{1}, 204$ (a. 1692), ,uricele lui cele bătrăne” $I_{2}, 39$ (a. 1702), „den zile bătrăne” $I_{2}$, 76 (a. 1753, rezumat). Sintagma „țuică bătrînă” este o reminiscență din această perioadă, așa cum sînt și toponimele Măgura Bătrînă (la est de Cîmpulung Moldovenesc, județul Suceava), Plaiul Bătrîn (la vest de Boboiești, județul Neamț), Jijia Bătrînă (vechea albie a rîului Jijia) sau Jiul Bătrîn (baltă în județul Dolj).
} 
Așadar, chiar dacă ceea ce propune perspectiva modernă este o identificare clară a variației semantice ale lexemelor și tratarea lor ca atare la nivelul de limbă în care funcționează, acest lucru nu înseamnă nicidecum reducerea variantelor semantice la una singură, a normei literare. Exemplificările din studiile coseriene nu trebuie să inducă această idee, deoarece ele sînt doar ilustrative, nicidecum prohibitive. Obiectivele studiilor corespunzătoare perspectivei moderne au fost eminamente teoretice. Aplicaţia propriu-zisă a teoriei ar trebui să fie vizată în primul rînd de către lexicografi, însă, spre deosebire de încercările de aplicare în lexicografie a rezultatelor la care s-a ajuns prin analiza cîmpurilor din perspectiva tradițională, perspectiva modernă nu s-a bucurat de asemenea realizări. Potrivit obiectului de cercetare identificat, adică numai zone ale vocabularului care se constituie în cîmpuri lexicale, posibilitățile contribuțiilor în lexicografie se reduc la tratarea cuvintelor care fac parte dintr-un cîmp lexical. Lipsa componentei diacronice (ca istorie a unei limbi, nu ca trecere de la o limbă la alta) din eșafodajul teoretic al perspectivei moderne, nu elimină cercetarea de tip diacronic a zonelor organizate (care implică interdependențe semantice) ale lexicului unei limbi, tot aşa cum nu elimină nici variația sa sincronică. De fapt, în planul limbii, nu există vreo diferență între variația sincronică și cea diaconică, pentru că variația dicronică nu este decît un rezultat al variaţiei sincronice sau, mai corect spus, o conservare a unei variaţii sincronice. Exemplele de mai sus arată că instrumentrarul și rezultatele abordării din a doua etapă a cîmpurilor lexicale pot aduce o importantă contribuție în lexicografie, urmărind variația semantică atît în plan sincronic, cît și în plan diacronic.

\section{Concluzii}

Perspectiva diacronică a avut un rol determinant în demersul teoretic care a condus la identificarea cîmpurilor lexicale. Istoricul teoriei cîmpurilor lexicale arată că există două perioade care se disting prin metodă și obiective. În perioada dintre anii '30 și începutul anilor '60, cînd obiectivul a fost demonstrarea existenței cîmpurilor lexicale, în planul metodei s-a impus cercetarea istoriei unui cîmp onomasiologic. În acest fel s-au putut identifica deplasările de conținut semantic de la un termen la altul în interiorul aceluiași cîmp onomasiologic și, implicit, a raporturilor între termenii respectivului cîmp. Ceea ce a constituit un instrument de cercetare, perspectiva diacronică, a devenit pentru cercetătorii de mai tîrziu un obiectiv practic, însă cu unele modificări, adică: prezentarea istoricului detaliat al fiecărui termen în parte a unui cîmp onomasiologic, fără nici un interes asupra raporturilor dintre termeni. Astfel de lucrări nu sînt decît niște dicționare detaliate ale istoricului termenilor unui cîmp onomasiologic, chiar dacă conțin în titlu sintagma „cîmp lexical”.

Pentru teoreticienii din această primă perioadă, abordarea diacronică s-a impus ca o necesitate metodologică, nu în urma unei decizii în defavoarea unor alte metode, ci ca singura modalitate prin care se putea demonstra propriu-zis dependența între termenii ce formează un cîmp lexical. Constituirea instrumentarului pentru o analiză semantică în cadrul lingvisticii structurale a permis fixarea unui alt obiectiv: identificarea tipurilor de raporturi dintre termenii unui cîmp prin identificarea semelor specifice. Caracteristica definitorie a acestei de-a doua perioade este analiza unui cîmp în cadrul unei limbi funcționale, adică în cadrul unei variante sincronice sau diacronice a unei limbi istorice. Identificarea semnificaţiei unui cuvînt la nivelul limbii funcționale în care se găsește nu trebuie confundată cu limitarea cercetării unui cuvînt în cadrul unei singure limbi funcționale. Cercetarea poate și chiar trebuie să aibă în vedere variația semantică a termenilor care intră în componența cîmpurilor lexicale atît în plan sincronic, cît și în plan diacronic. Rezultatele acestui tip de cercetare sînt utile în lexicografie, definițiile și structuarea articolelor devenind mai clare și mai apropiate de realitatea limbii.

\section{Bibliografie}

Coseriu, E. (1994). Prelegeri şi conferințe (supliment al „Anuarului de lingvistică şi istorie literară”, XXXIII, 1992-1993, Seria A - Lingvistică), Iaşi.

Coseriu, E. (2001a). Pour une sémantique diachronique structurale, în „L'Homme et son langage”, Éditions Peeters, Louvain Paris - Sterling, Virginia, p. 253-313, ed. I: 1964. 
Coseriu, E. (2001b). Vers l'étude des structures lexicales, în „L'Homme et son langage”, Éditions Peeters, Louvain - Paris Sterling, Virginia, p. 215-252, ed. I: 1966.

DA = Dicționarul limbii române, București, 1913-1949.

Diogenes Laertios (2001). Despre viețile și doctrinele filosofilor, traducere de C.I. Balmuș, studiu introductiv și comentarii de A.M. Frenkian, Polirom, Iași.

Escobedo Rodríguez, A. (1992). El campo léxico 'hablar’en español, Servicio de Publicationes de la Universidad de Granada, Granada.

Ghibănescu, Gh. (1906-1915). Ispisoace și zapise (Documente slavo-române), I-IV, Tipografia „Dacia”, Iași.

Hallig, R. \& Wartburg, W.v. (1963). Begriffsystem als Grundlage für die Lexikographie (Versuch eines Ordnungsschemas), 2. neu bearbeitete und erweiterte Auflage, Akademie Verlag, Berlin, ed. I: 1952.

Iliescu, M. (2008). Semantica descendenților romanici ai lat. vetulus, în Miscelanea Romanica (1956-2007), Clusium \& Scriptor, Cluj-Napoca, p. 221-228.

Jolles, A. (1973). Antike Bedeutungsfelder, în „Wortfeldforschung. Zur Geschichte und Theorie des sprachlichen Feldes”, Hrsg. von Lothar Schmidt, Wissenschaftiche Buchgesellschaft, Darmstadt, p. 104-115, ed. I: 1934, CrossRef.

Moscal, D. (2013). Teoria cîmpurilor lexicale. Cu aplicație la terminologia populară a formelor de reliefpozitiv, Editura Universității „Alexandu Ioan Cuza”, Iași.

Porzig, W. (1973). Wesenhafte Bedeutungsbeziehungen, în „Wortfeldforschung. Zur Geschichte und Theorie des sprachlichen Feldes", Hrsg. von Lothar Schmidt, Wissenschaftiche Buchgesellschaft, Darmstadt, p. 78-103, ed. I: 1934, CrossRef.

Saussure, F. de (1922). Cours de linguistique générale, publié par Ch. Bally et Al. Sechehaye avec la collaboration de A. Riedlinger, Payot \& Cie, Paris.

Trier, J. (1973a). Der deutsche Wortschatz im Sinnbezirk des Verstandes. Von den Anfängen bis zum Beginn des 13. Jahrhunderts, Zweite Auflage, Carl Winter Universitätsverlag, Heidelberg, ed. I: 1931.

Trier, J. (1973b). Deutsche Bedeutungsforschung, în „Wortfeldforschung. Zur Geschichte und Theorie des sprachlichen Feldes”, Hrsg. von Lothar Schmidt, Wissenschaftiche Buchgesellschaft, Darmstadt, p. 116-128, ed. I: 1934.

Trier, J. (1973c), Altes und Neues vom sprachlichen Feld, în „Wortfeldforschung. Zur Geschichte und Theorie des sprachlichen Feldes", Hrsg. von Lothar Schmidt, Wissenschaftiche Buchgesellschaft, Darmstadt, p. 453-464, ed. I: 1968.

Wartburg, W. v. (1931). Das Ineinandergreifen von deskriptiver und historischer Sprachwissenschaft, în „Berichte über die Verhandlungen der Sächsischen Akademie der Wissenschaften zu Leipzig. Philologisch-historische Klasse”, 83/1, p. 1-23.

Wartburg, W.v. (1946). Problèmes et méthodes de la linguistique, PUF, Paris.

Wartburg, W.v. (1972). Betrachtungen über das Verhältnis von historischer und deskriptiver Sprachwissenschaft, în „Mélanges de linguistique offerts à Charles Bally”, Slatkine Reprints, Genève, p. 3-18, ed. I: 1939.

Weisgerber, L. (1973), Vom inhaltlichen Aufbau des deutschen Wortschatzes, în „Wortfeldforschung. Zur Geschichte und Theorie des sprachlichen Feldes", Hrsg. von Lothar Schmidt, Wissenschaftiche Buchgesellschaft, Darmstadt, p. 193-225, ed. I: 1939. 